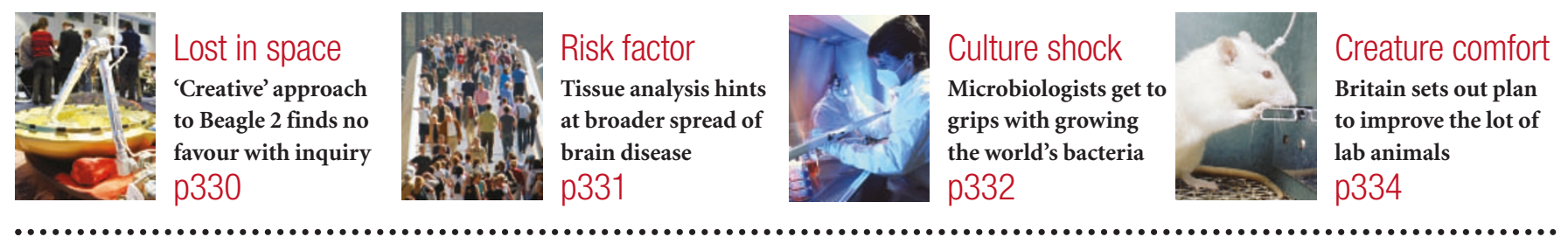

\title{
Clinicians win fight to overturn patent for breast-cancer gene
}

\section{Alison Abbott, Munich}

A European patent that gave a company in Utah the exclusive right to perform diagnostic tests for a breast-cancer gene has been revoked.

In a landmark ruling on 18 May, the European Patent Office (EPO) granted an appeal against Myriad Genetics of Salt Lake City over its patent on the gene BRCA1. The office ruled that Myriad's claim was invalid because its original submission, made in the United States in 1994, contained a number of small errors in the gene's sequence.

The finding sheds light on the race in the early 1990s to patent genes of interest, while updating their accuracy, even as other researchers put versions of the same sequences in public repositories, such as GenBank.

Mutations in BRCA1 predispose women to some hereditary forms of breast cancer. Myriad's patent had incensed European clinicians because it allowed the company to require that all tests for the gene be done at its labs in Salt Lake City (see Nature 413, 443; 2001). Many researchers refused to comply, continuing to use their own tests instead.

A group of opponents appealed against the patent, claiming that the identification of the gene owed too much to research in the public domain to justify Myriad's claim to have made an inventive step.

In 1990, several academic research groups formed an international consortium to home in on the gene, which had been located to a particular region of chromosome 17 (J. M. Hall et al. Science 250, 1684-1689; 1990). The collaboration met regularly and pooled its data.

Once the region containing the gene had been narrowed down, several groups in the consortium, including some researchers from the University of Utah who went on to found Myriad Genetics, began competing against each other to identify the gene's sequence.

In its dash to secure rights on the gene, Myriad staked its first claim in a patent filed to the US Patent and Trademark Office in August 1994. Over the next twelve months, it filed an additional seven patents on the BRCA1 gene with the US office, updating sequence information as it went along. It brought its claims

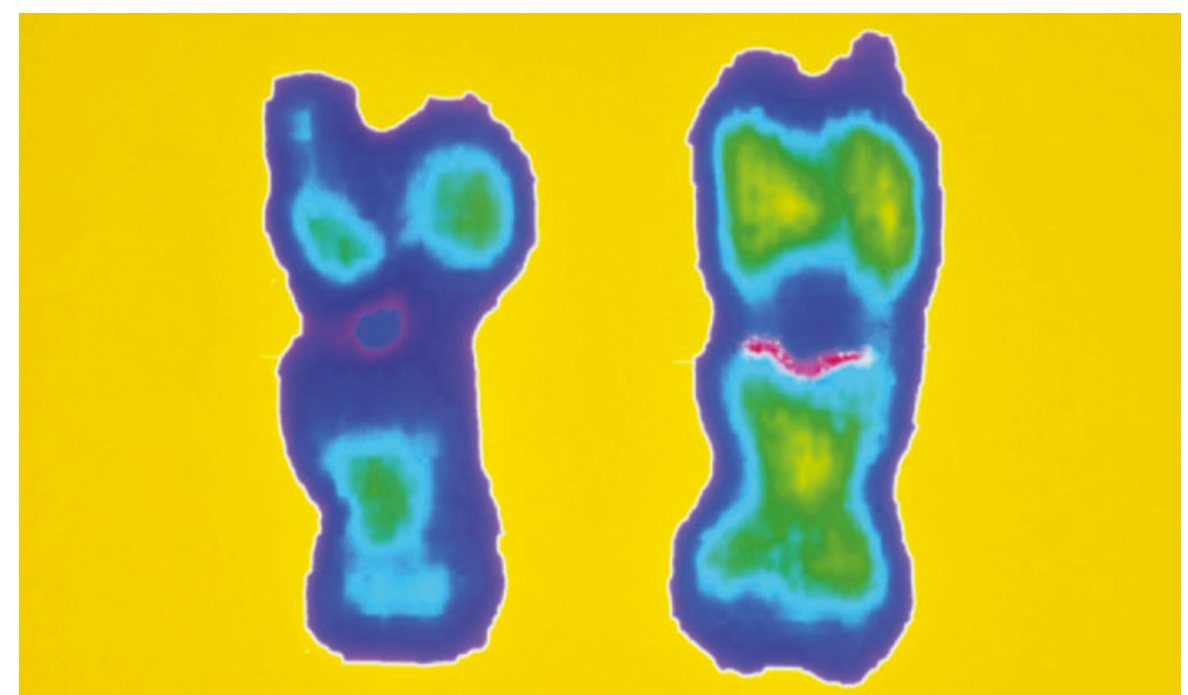

Women with only one copy of the BRCA1 gene (red) on chromosome 17 may be at risk of breast cancer.

together in a single patent application to the EPO in August 1995. By this time, the gene's sequence was well known in the community.

In its EPO application, Myriad referred to its first US filing in August 1994 as its "priority date", but the examining officer spotted that the sequence, which encodes a protein made up of 1,864 amino acids, was shorter than it should have been. The officer insisted that Myriad change the priority date to that of its second US filing, in September 1994, failing to notice the less obvious differences between the sequence filed then and the correct one. In fact, ten amino acids dotted throughout the protein were incorrect.

\section{Ruled out}

These differences were only corrected in Myriad's fifth US application, filed in March 1995. By this time, others, including Myriad scientists, had published information on the sequence and so it was no longer novel, and thus no longer patentable, ruled the EPO's appeal board. This ruling will not directly affect Myriad's US patent.

"Finding such small differences in large genes is close to impossible," says Siobhan Yates, head of biotechnology at the EPO. Priority documents are always in a different format from EPO application documents, ruling out electronic comparisons, she says.

Similar sequence differences have led to other EPO gene patents losing their priority dates, including patents claimed by Genentech in South San Francsico on tissue plasminogen activator, in which three nucleotides were incorrect, and the HIV virus, which had four errors. As a result, the scope of both patents was restricted.

"The EPO has sent a clear signal that it requires strict accuracy of information," says Jacques Warcoin, patent attorney for several of Myriad's opponents, including the Curie Institute in Paris, whose scientists spearheaded opposition to the patent.

But some opponents say that they wish the EPO had revoked the patent on matters of principle, rather than on technicalities. "Our concerns are about how the inventive process envisioned in patent law can be reasonably applied to disease genes," says Mike Stratton, a geneticist at the Sanger Institute near Cambridge, UK, who was part of the original consortium seeking the breast-cancer gene.

Myriad has two other patents covering $B R C A 1$ and its mutations, and opposition hearings for them have been scheduled for January 2005. It has until the end of the year to oppose the patent's revocation. Myriad did not respond to requests for comment. 